\title{
Addressing the environmental risk from the mudflow disaster in Sidoarjo
}

\author{
Boby Bagja Pratama ${ }^{1, *}$ and Supriatna ${ }^{2}$ \\ ${ }^{1}$ Post-graduate Student of School of Environmental Sciences, University Indonesia \\ ${ }^{2}$ Faculty of Geography, University Indonesia
}

\begin{abstract}
This research focuses on disaster mitigation of Sidoarjo Mudflow since 2005 until 2018. This research aims to analyze and mapping mudflow pattern since 2005. It uses Geographical Information System or spatial information as tools to describe and analyze major environmental problems. It examines data Landsat 7 and 8 Imagery between 2005 and 2018 for calculating the area of impact from Sidoarjo Mudflow. It takes further analysis from research which using Landsat Imagery to calculating sedimentation in Mahakam Rivers. Moreover, addressing the environmental risk at Madura Gulf from Sidoarjo Mudflow in the last few years, this research analyzes the impact of mudflow distribution pattern in and social adaptation in retrospective view. This research found that sedimentation fom the mudflow is making more difficult to calculate the impact and composing mitigation plans. To address the environmental risk from the mudflow disaster, explores spatial information regarding changes from Sidoarjo Mudflow to social adaptation, such as adaptation to looking for fishing area and fishing intensity.
\end{abstract}

\section{Introduction}

Sidoarjo Mudflow is one of the major environmental problems in Indonesia[1]. Mitigation that has been done by the government was redirecting the mud flows to nearest water bodies. It flowed to Madura Gulf through Porong Rivers. With mudflow debit around $30,000-60,000 \mathrm{~m} 3$ every day in the recent years[2]. It clearly would affect water quality and environmental sustainability. According to document that was published by Audit Lingkungan BPK-RI[1] at the point Forecast of Environmental Impact, flowing to water bodies will causing an environmental risk. Such as dust and clay that contained in the mud will take a long time to sediment at the riverbed/seabed. The consequence of flowing muds or sediment transport, the sediment will spread and covering coral reefs and mangroves[3, $4,5]$. Because coral reefs and mangroves are places for fishes spawning grounds[3, 6]. It would disturb aquatic ecosystem and harm fishes population growth and influence fisheries catch rate[7,3]. Considering characteristic of the mudflow that not fall under hazardous and toxic waste[3, $6,1,2]$, the government stated that it is safe for the environment $[8,1]$. However, changes in water clarity, turbidity $[9,8,1,2]$, and fishing statistic[10, 9, 11]

\footnotetext{
${ }^{*}$ Corresponding author: boby.bagja@gmail.com
} 
indicated that mudflow has ecological impact in the ecosystems and its Life Cycle Assessment as a metric to achieve sustainable development goals.

There is a correlation between aquatic ecosystem and sedimentation[7, 4, 5]. Habitat characteristics affect natural selection and living quality to the organism[7]. The impact can be seen from bottom levels to the top of foods chain[7, 4, 5]. The primary organism is the one that highly affected from sedimentation because of the disturbed photosynthesis process from waters turbidity[6]. With interrupted sunlight penetration, sedimentation also affects phytoplankton productivity as primary nutrient producer[3, 6].

This research is highlight Sublethal effect of sedimentation regarding aquatic biota and habitat. According to the other research, the long-term sedimentation on the water might cause depletion of dissolved oxygen and disturbance in the photosynthesis process. It also might damage the aquatic biota from clogged gills[3, 6, 9]. According to research by Scrivener et. al.[4] the migration pattern Salmonidae family at the Fraser River, Salmon juvenile using non-natal river that was cleaner, or using different river with the natal river, to avoid mud contamination for reducing stress by sedimentation. Fish migration is generally caused by intrinsically genetic and extrinsic factor, on connection to these research, habitat quality (phytochemical factor) affected fish migration[5]. However, EIFAC (European Inland Fisheries Advisory Commission) in 1964[3], states that aquatic ecosystem could still sustain when TSS concentration $25-80 \mathrm{ppm}$. Although productivity is declined compared with TSS concentration under $25 \mathrm{ppm}[3]$.

EIFAC research findings are:

- High TSS concentration in water bodies affect aquatic biota. Thus, rising biota mortality that affects growth rate and disease resistance.

- Constraining spawn and larvae growth

- Altering natural mobility

- Reducing foods (Affecting phytoplankton productivity)

According to numbers of research, mudflow into water bodies and sedimentation from mudflow have spatial variation and temporal variation[12]. Physical sedimentation also changes landform in the water bodies such as; shallowing and increasing shoreline. Sedimentation changes landform in the Lower Yellow River thus narrowing river bodies[13]. In the connection of this research is high and constant sedimentation will changing Porong River and Madura Gulf.

Spatial Information which related to Sidoarjo Mudflow is required for further mitigation plans. In particularly, mudflow distribution pattern from recent years. Mitigation plans which related for flowing mud to Porong River were taken by Indonesian government[1][2]. The action is considering social urgency, massive flows, and that natural sedimentations that already happened from past century at the Porong River Estuary from Kali Brantas and Bengawan Solo River[8][1][2]. According to past research using plotting GPS (Global Positioning System) and GIS (Geographical Information System), the direction of Sidoarjo Mudflow was going to Eastern from Sidoarjo coastline[11].

\section{Data and methods}

This research use quantitative approach and retrospective longitudinal approach as time series research from the past to present. It will use data from 2005 to 2016 , that will be analyzing between variable with the spatial information as measuring tools. Furthermore, this research will see the changes in sedimentation or mudflow pattern since 2005 to present. In addition, this research use ex-post facto approach because of the data characteristics and research phenomenon was happening since 2005.

However, on the other research, it is theorized that accumulated sedimentation in Madura Gulf are not only from Sidoarjo Mudflow but also from natural events[8, 1, 14, 2]. 
It derived from sedimentation Kali Brantas and Bengawan Solo River[8, 1, 14, 2]. Moreover, delimitation on this research is only analyzing sedimentation from Sidoarjo Mudflow.

Object of these research are; Landsat Imagery. Landsat imagery population data are Landsat 7 Imagery and Landsat 8 OLI TIRS Imagery Madura Gulf from 2005 to 2016. It was taken from path 118 and row 65, earthexplorer.glovis.gov. Data from 2005 will be used as data control and data from 2006 to 2016 will be analyzed the spatial changes regarding Sidoarjo Mudflow. In addition, cloud coverage are also one of main criteria. High cloud coverage would affect negatively the accuraccy resulted from algorithm processing. Ideal Cloud Coverage (CC) that used in this research are below 50\%. Algorithm that will be used in this research is Budhiman Algortihm:

$$
\operatorname{TSS}(m g / l)=A^{*} \exp \left(S^{*} R(0-) \text { red band }\right)
$$

with:

TSS $=$ Total Suspended Solid (Sediment)

$\mathrm{R}(0-) \quad=$ Iradian reflectance

$\mathrm{A}$ and $\mathrm{S}$ are equation variable

This research will be conducted by overlaying and analyzing time-series Landsat data to produce sedimentation pattern from 2005 to 2016 . From that result, it will be analyzed biological capacity or carrying capacity Madura Gulf to support living organism. Hypothetically, Madura Gulf is semi-closed gulf with high incoming current to Northern parts Madura Gulf from the Java Sea. Therefore, sedimentation patterns trends are going South from Porong River Estuary.

\section{Result and discussion}

In general, the condition of the Madura Strait has occurred silting due to the high sedimentation of the Bengawan Solo River[15]. Based on the research results, sedimentation fluctuations vary each year. Sedimentation occurring in the research area varies due to the dynamics of seawater. The change is in the form of sedimentation that precipitated and carried away to the Java Sea.

Sidoarjo mudflow occurred in May 2006, that Sidoarjo Mudflow has not entered the water bodies so that the sedimentation is still a natural factor. From the results of image processing in 2005 seen sedimentation that occurs due to natural factors. In 2006, the rate of sedimentation declined compared to the previous year. This can be due to natural factors, such as the sea currents dynamics, weather, and natural sediment deposition, that still have a greater impact than the Sidoarjo mudflow sedimentation process. Chronologically in August 2006, the sedimentation of Sidoarjo Mudflow to water bodies has not been massive. 


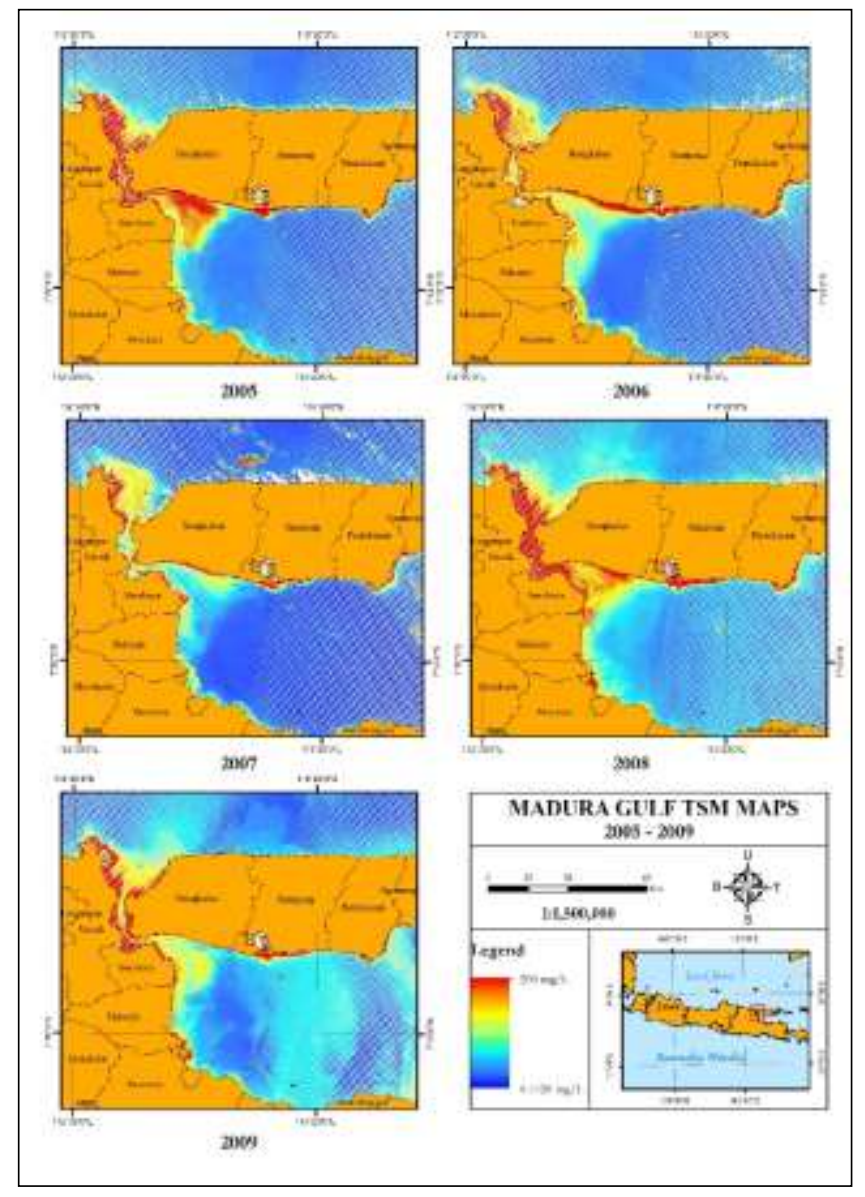

Fig 1. Mudflow Maps TSM 2005-2009 (Annotation : a. 2005 Mudflow Map, b. 2006 Mudflow Map, c. 2007 Mudflow Map, d. 2008 Mudflow Map, and e. 2009 Mudflow Map)

In 2007 the sedimentation rate are declined, although the sedimentation from Sidoarjo Mudflow to water bodies has been going on for 1 year. This is caused by the volume of sedimentation that has not been massively accumulated, so that natural processes such as sedimentation and dissolution by the current are still more dominant in the water bodies. In June 2008 sedimentation process due to Sidoarjo Mudflow in Madura Strait began to increase. According to research in Kali Porong on the southern coast of Sidoarjo also increasing in TSM levels at the water bodies. The amount of TSM concentration distribution in Madura Strait is higher than in previous years.

From image processing in October 2009, the sedimentation distribution rate began to decline compared to the previous year. A higher sedimentation rate in 2008 showed that the natural sedimentation from Brantas River added with Sidoarjo Mudflow Sedimentation had a considerable impact on the distribution of sedimentation in water bodies. But in 2009, natural factors began to reduce and restore the sedimentation on the Madura Strait. Hence, reducing the sedimented area in Madura Strait. 


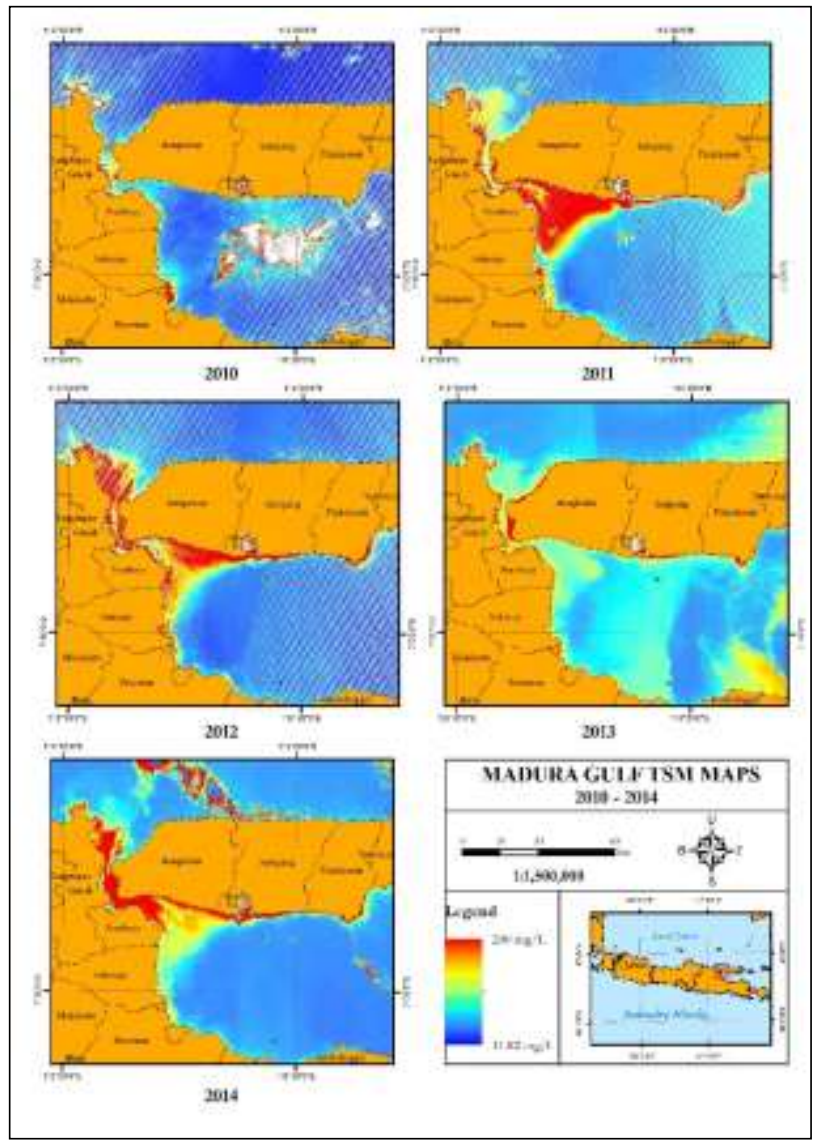

Fig 2. Mudflow Maps TSM 2010-2014 (Annotation : a. 2010 Mudflow Map, b. 2011 Mudflow Map, c. 2012 Mudflow Map, d. 2013 Mudflow Map, and e. 2014 Mudflow Map).

In 2010 is similar to that in 2009 , sedimentation rates in water bodies began to be reduced naturally. The condition of sedimentation distribution in Madura Strait based on research are decreased significantly compared to 2008 when Sidoarjo Mudflow started to enter the water bodies. From the results of image processing in 2011 there was an increase in the distribution of Sidoarjo Mudflow in the water bodies. The sedimentation area are concentrated in the southern part of the Madura Strait. Sidoarjo Mudflow waste that has occurred during the last 5 years began to accumulate in the Madura Strait. Sedimentation distribution that in the previous year accumulated in the south of the strait, in 2012 began to drift into the Madura Strait. Increased sedimentation causing decreased water quality in exposed areas. Based on information from Kenjeran Fisherman, the area is no longer productive for fishing area.

In 2013, the concentration of sedimentation began to decreased compared to the previous year. It can be proved that there is a cycle of sedimentation absorption by nature, either because it settles or is carried away by the sea current. However, from image processing result, it can be observed that the sediment tends to be still quite high in the coastal area of Madura Island. Based from information having a siltation up to 1-2 meters. Sedimentation distributed again in 2014 at the Madura Strait. Sedimentation distribution also increased in the southern coastal area of Madura Island, although the distribution in the coastal area of Sidoarjo regency began to decreasing. 


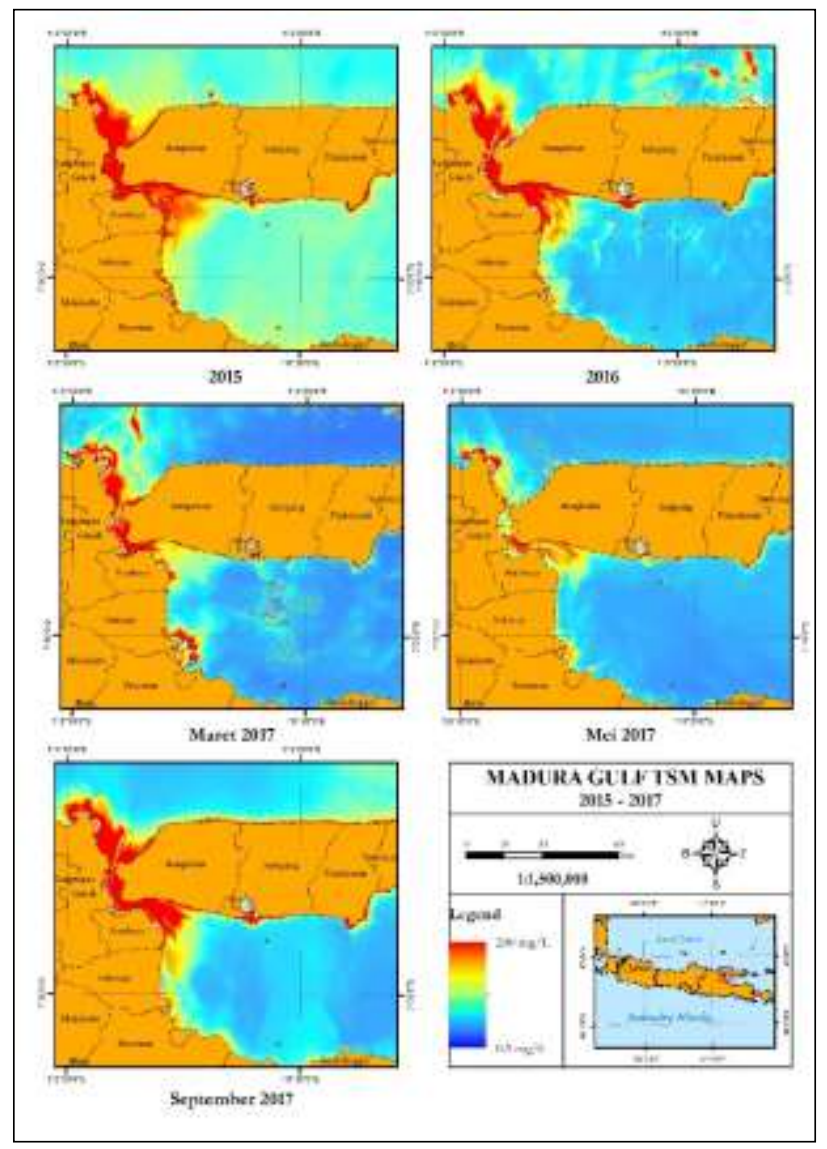

Fig 3. Mudflow Maps TSM 2015-2017 (Annotation: a. 2015 Mudflow Map, b. 2016 Mudflow Map, c. March 2017 Mudflow Map, d. May 2017 Mudflow Map, and e. September 2018 Mudflow Map).

In 2015 the distribution of sedimentation continues to increase from 2014, as seen in data processing above. The condition is suspected because the input of Sidoarjo Mudflow that accumulated a lot caused a high increase in Madura Strait. The cycle of reduction and restoration of the sedimentation distribution began to be hampered in this year, unlike the previous year where the distribution of sedimentation then decreased due to natural restoration. In 2016, sedimentation continues to increase as in 2015. Sedimentation is concentrated in the Strait of Madura. This is due to the ability of natural restorations unable to accommodate accumulations of the pollutants entering the water bodies. Because the sedimentation process is higher than the ability of the natural sedimentation absorption. In 2017, processing is done with 4 images to observe the trend of changes in one year. In March 2017 image, sedimentation was slightly less than in the previous year, but sedimentation is still high in the area of Madura Strait and Muara Kali Porong.

In May 2017, sedimentation are decreased for the Madura Strait. The condition is thought to be caused by seasonal changes, leading to the dry season, resulting in high waves and strong winds. Although not significant, the decline in sedimentation is considerably less than in March 2017. In September 2017 sedimentation are increased again. The increase in sedimentation is likely due to the decreasing rainfall in wet season in the Madura Strait. This results in the accumulation of sedimentation found in the waters. 


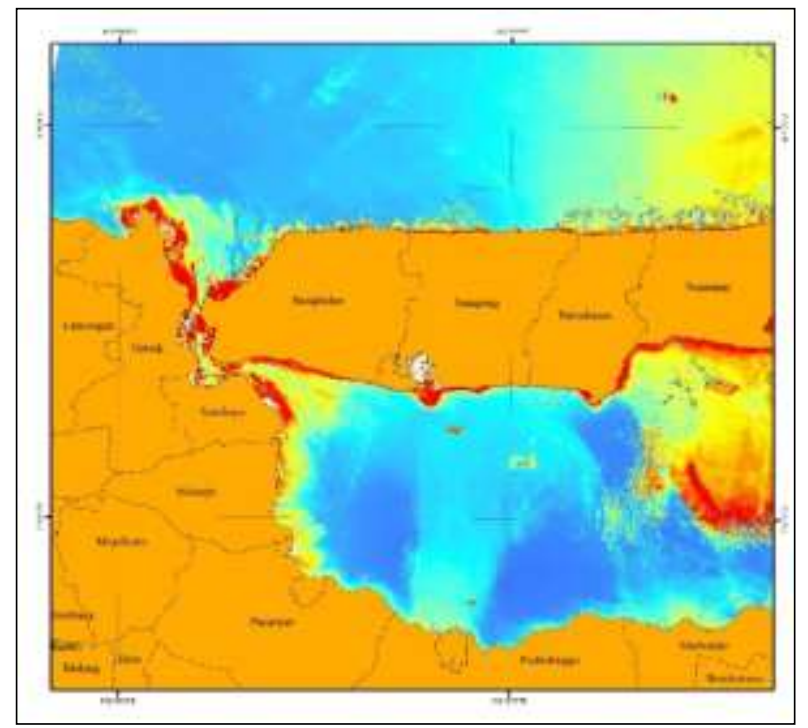

Fig 4. TSM Flow Map October 2017.

Similar to the annual natural cycle on the annual data processing, in October 2017, reduction of sedimentation distribution occurred in the Madura Strait. Based on the experience of researchers, in October began to enter the rainy season, so the process of adding water masses help reducing sedimentation deposition process in the water bodies.

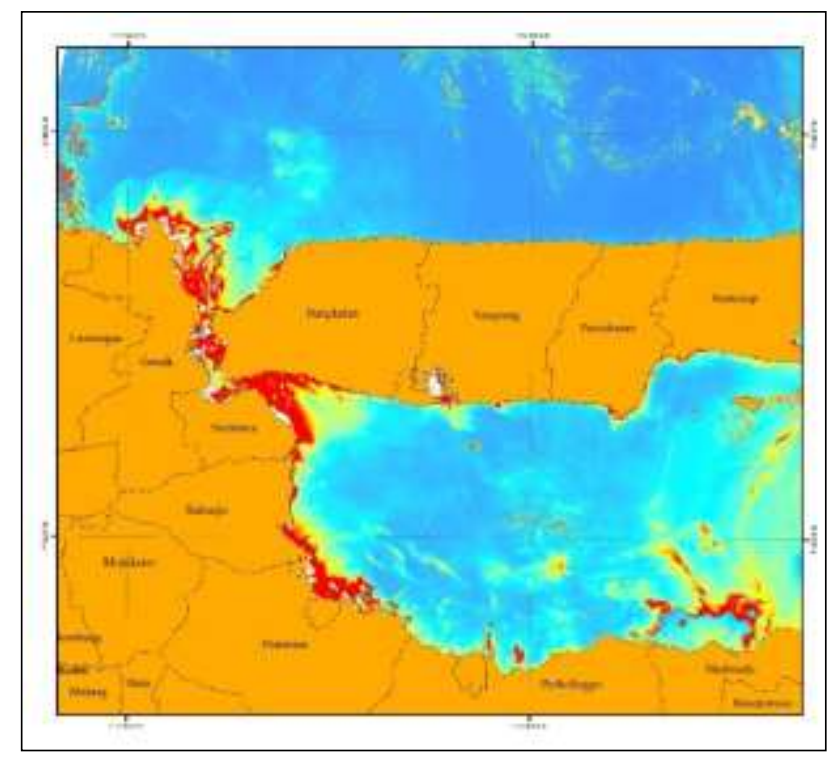

Fig 5. TSM Flow Map March 2018.

On the March 2018 map, the distribution of sedimentation again increases, and spreads from Porong River to Madura Strait. The high spread is due to seasonal changes from the rainy season to the dry season. Because of the low precipitation, the deposition process is significantly reduced, resulting in high sedimentation in the waters. Based on the results of 
image processing from 2005 to 2018, in the Madura Strait itself quite clear natural sedimentation occurs without input from Sidoarjo Mudflow. Natural sedimentation there is also a natural restoration process to reduce such sedimentation, such as rainfall, currents, and precipitation. Since the inclusion of the Sidoarjo Mudflow itself to the water bodies, especially the Madura Strait the intrusion adds to the burden of sedimentation reduction and tends to increase towards sedimentation rather than deposition or absorption process.

\section{Conclusion}

However, this paperwork has not states that sedimentation is the main factor of silting in Madura Strait. Although it had significant rationale in the silting and sedimentation. This paperwork also has not states that using spatial information are entirely reliable as main data nor with visually comparing and overlaying methods. Instead, with has been theorized based on data and theoretical approach. It can represent interraction between natural ecosystem and human based sedimentation.

\section{References}

1. BPK RI. Audit Lingkungan Lumpur Sidoarjo. Audit Lingkungan BPK RI, 224-264. (2009).

2. BPLS. Penanganan Luapan Lumpur ke Kali Porong. Retrieved from bpls.go.id: http://www.bpls.go.id/penanganan-luapan-ke-kali-porong/461-pengaliran-lumpur-kekali-porong-lama. (2014, Februari 24).

3. I. K. Birtwell, The Effects of Sediment on Fish and their Habitat. Ottawa: Canadian Stock Assesment Secretariat. (1999).

4. J. C. Scrivener, T. G. Brown, \& B. C. Andersen, Juvenile Chinook Salmon (Oncorhynchus tshawytscha) Utilization of Hawks Creek, a Small and Nonnatal Tributary of the Upper Fraser River. Canadian Journal of Fisheries and Aquatic Sciences Vol. 51, 1139-1146. (1994).

5. J. E. Rasmussen \& M. C. Belk, Individual Movement of Stream Fishes: Linking Ecological Drivers with Evolutionary Processes. Reviews in Fisheries Science \& Aquaculture, 25:1, 70-83. (2016).

6. Canadian Council of Ministers of the Environment. Canadian Water Quality Guidelines for the Protection of Aquatic Life: Total Particulate Matter. Canada: Canadian Environmental Quality Guidelines. (2002).

7. T. R. Southwood, Tactics, Strategies and Templets. Oikos, Vol. 52, No. 1, 3-18. (1988).

8. D. Fathurrohman, Masalah Pengelolaan Daerah Aliran Sungai (DAS) Brantas di Jawa Timur: Solusi dan Model Kolaborasi. Agritek Vol. 16 No. 5, 678-952. (2008).

9. S. W. Tjokrokusumo, Pengaruh Sedimentasi dan Turbidity pada Jejaring Makanan Ekosistem Air Mengalir (Lotik). Jurnal Hidrosfir Indonesia, Vol. 3, 137-148. (2008).

10. Aunurohim, D. Saptarini, \& D. Yanthi, Fitoplankton Penyebab Harmful Algae Blooms (HABs) di Perairan Sidoarjo. Surabaya: ITS Institutional Repository. (2006).

11. N. Hidayah \& A. B. Cahyono, Evaluasi Perubahan Tutupan Lahan Menggunakan Citra Satelit Mutitemporal Tahun 2009-2011. Journal Geodesy and Geomatics, Vol 8, No 1. (2012).

12. Z. Zheng, Jingli Ren, Yunmei Li, Chuangchun Huang, Ge Liu, Chenggong Du, \& Heng Lyu. Remote Sensing of Diffuse Attenuation Coefficient Patterns from Landsat 8 OLI Imagery of Turbid Inland Waters: A Case Study of Dongting Lake. Science of Total Environment Vol.573, 39-54. (2016).

13. Chen Jian-guo, Zhou Wenhao, \& Chen Qiang, Reservoir Sedimentation and Transformation of Morphology in the Lower Yellow River During 10 Year's Initial 
Operation of the Xiaolangdi Reservoir. Journal of Hydrodinamic Vol.24, 914-924. (2012).

14. R. Kurnia \& B. Widodo, The Influence Of Hydrodynamics on the Spread of Pollutants and Sedimentation in the Confluence of Two Rivers. International Seminar on Innovation in Mathematics and Mathematics Education, Vol. 7, No. 123, 6115-6123. (2013).

15. P. Hoekstra, The development of two major Indonesian river deltas: morphology and sedimentary aspects of the Solo and Porong delta, East Java. Proceedings KNGMG Symposium 'Coastal Lowlands, Geology and Geotechnology' (pp. 143-159). Dordrecht : Kluwer Academic Publishers. (1987). 